Colloquia Litteraria

UKSW

$1 / 2017$

WOJCIECH KUDYBA

\title{
A MONOGRAPH IS NECESSARY. A MONOGRAPH IS IMPOSSIBLE
}

A monograph is necessary. The strong status of the monograph is decided by institutions created in order to manage the field of scientific research. The empirical status of the monograph's necessity is confirmed by the instructions of Parametryczna Ocena Jednostek Naukowych (Parametric Assessment of Scientific Units). Doubts about the possibility of constructing one's own monograph, which results in a lack of monographs in the published texts of a given scholar, create the risk of putting this scholar in a scholarly abyss, which endangers the structure of the scientific unit he/she is a member of. Difficulties in distinguishing between a monograph and other scholarly texts should not strengthen these doubts. The notion of a monograph proposed by Ministerstwo Nauki (Ministry of Science) does not belong to the order of typology but to the order classification (it is, therefore, based on the idea that all features which constitute a concept should be present in all texts belonging to this class of phenomena). The Ministry of Science provides this definition:

A "Monograph" is a scholarly text (at least 120 ooo characters long) published as a book or a separate volume, dealing with some particular issue in a way that is exhaustive, original and creative. Edited source texts and lexicographies may be regarded as monographs. Monographic articles published in periodicals cannot be considered monographs. ${ }^{1}$

${ }^{1}$ See www.nauka.gov.pl [access 30.05.2011]. 
This definition is in accordance with the contemporary Polish language. The dictionary definition runs as follows: "Scholarly work dealing with the exhaustive treatment of one particular issue, of texts by one person". ${ }^{2}$ However, it is difficult not to see that this definition does not respect the poetics of the discourse of different scholarly disciplines. Both its plurality of meanings (fuzziness of concepts such as 'exhaustive', 'original', 'creative'), as well as its firmness (about the length) are grounded in pragmatic orientation. A utilitarian goal of this definition and its wide address (it is, after all, directed to all branches of sciences and social sciences) make it impossible to narrow this concept in such a way that it could be treated as a generic qualifier. The borders have been drawn so widely that the monograph-according to the quoted formula-is, in general, every scholarly book which is to some degree original and which is longer than the standard 120 pages.

\section{Monographs of Monographs}

Such a situation would not give any reasons for concern if it was not for the fact that certain disciplines have their own understanding of the term "monograph". In literary studies (history of literature) the monograph is still a scholarly genre with some specific features. Słownik terminów literackich (Dictionary of Literary Terms leaves no doubts about it:

Monograph [...]-one of the basic forms of texts in the Humanities; a comprehensive dissertation (treatise) aiming at an exhaustive and many-sided presentation of a chosen set of issues. In literary studies we come across monographs dealing with particular texts, writers, literary periods, literary genres, and theoretical problems. The most common form is a monograph about a particular writer $[\ldots]^{3}$

\footnotetext{
${ }^{2}$ Słownik wyrazów obcych, ed. by Elżbieta Sobol, Warszawa 2002.

${ }^{3}$ Michał Głowiński, Teresa Kostkiewiczowa, Aleksandra Okopień-Sławińska, Janusz Sławiński, Słownik terminów literackich, ed. by. J. Sławiński, 3rd edition, extended and corrected, Wrocław, 1998.
} 
We do not have many texts dealing with what might be called a theory of the monograph. ${ }^{4}$ It is all the more important to note that from the perspective of some theoreticians the monograph is a genre clearly connected with a 'personal' view of the history of literature that it is not a synthesis of genres, trends or problems, but the synthesis of the works of one writer. Stefan Sawicki was one of the first scholars to write about the monograph in this way:

New phenomena in literature are always connected with the works of one particular writer. A literary genre is only a space for these achievements. The history of literature is created by people, changes are made by entities which can be briefly described as: Kochanowski, Norwid, Gombrowicz, which are rationalized pictures of these writers, re-created through the interpretation of their works [...] Writers' individualities are constitutive for the character of particular tendencies and trends, they are the key factors in the history of literature, even though they are limited by the conventionalized tradition. ${ }^{5}$

It seems that also today it would be difficult to imagine the history of literature without the monograph. It is still a popular form of synthetic scholarly works (after all, history of literature is doomed to synthesis). At the same time, a literary scholar's works are increasingly rarely grounded in literary theory. Which guidelines could today direct us towards a modern reading of literary textsreading removed not only from simplistic naivety but also from the dangerous reliance on individual research concepts? The answer to these question does not have to be unequivocal. However, it requires separate and thorough consideration. This answer seems to be inevitable: after all, each interpretative procedure implies some

\footnotetext{
${ }^{4}$ See Maria Żmigrodzka, “Osobowość i życie pisarza w monografii” in Problemy metodologiczne wspótczesnego literaturoznawstwa, ed. by Henryk Markiewicz and Janusz Sławiński, Kraków 1976, 80-99; Stefan Sawicki, "O syntetycznym ujmowaniu literatury”, in Stefan Sawicki, Poetyka. Interpretacja. Sacrum, Warszawa 1981, 154-171. ${ }^{5}$ Stefan Sawicki, op. cit., 164.
} 
theory. The problem is that literary studies long ago diverged from the real needs of a reader. The approaches which are oriented in a specific way to the literary synthesis in a historical perspectivesuch as narratology or New Historicism-spread the conviction that literary synthesis is not only necessary, but that it is also impossible. ${ }^{6}$ They lead to the position in which a literary scholar today, if $s /$ he wants to keep abreast of literary studies, must give up something which is an element of the identity of his/her own research field. Does s/he really, in the name of the 'Zeitgeist', have to forget about the existence of means to synthesize material and-freed from the rigours of scholarship-should joyfully devote him/herself to writing relatively original books longer than 120 ooo characters?

\section{Controversies with Studying of Literature}

Let us ask once again: is the monograph still possible after deconstruction? Are we still able to create a synthetic picture of the works of one particular writer on the basis of the analysis and interpretation of his/her texts? In what way can such research procedures be grounded in theory? Contemporary literary studies induce us to ask such questions, which are more and more often inspired by deconstruction. The key 'achievements' of deconstruction include, after all, such concepts as depriving a text of its autonomy, textualization of a context, and a critique of interpretation. ${ }^{7}$ Let us briefly summarize this position: a text, in the view of post-modernist literary scholars, loses its autonomy. It cannot be 'separated' either from a reader and his/her 'ways of reading', or distinguished from the context (created both by works and their interpretations). A text has no clear borders, becoming a 'nebula' in the all-embracing cosmos

\footnotetext{
${ }^{6}$ A review of some of the positions is presented in: Katarzyn Kasztenna, $Z$ dziejów formy niemożliwej. Wybrane problemy historii i poetyki polskiej powojennej syntezy teoretycznnoliterackiej, Wrocław 1995.

7 Jonathan Culler writes about it in "Dekonstrukcja i jej konsekwencje dla badań literackich:, transl. by Maria Bożenna Fedewicz, „Pamiętnik Literacki” 1987, i. 4, 231272. See also Anna Burzyńska, Krajobraz po dekonstrukcji (part I), „Ruch Literacki” 1995, i. 1, 73-91.
} 
of 'textuality', or to be more exact 'intertextuality'. In this it has at the same time the features of 'presence' and 'absence'-and evades cognition. The interpretation of a 'text' understood in this way cannot be successful because of obvious reasons: the relativity and 'dispersion' of its meanings is so great that our discourse about this text turns out to be one more 'concentration of semiosis' around countless, ceaselessly oscillating intertextual references of an individual text. It is possible to show some of the areas of these references, conducting a free 'play with the text' or to show its 'alterity', to reveal aporias of metatextual discourse. ${ }^{8}$ Let us repeat: the material which a literary scholar analyses is not, according to deconstructionists, something given beforehand; it is constructed during the process of writing. Thus, reading is not an act of opening yourself onto the text, it is not its reception, but it is a creative act- giving shape to material through language. That is the reason why the post-modernist attitude to the ways of synthesizing literature is concentrated almost entirely on the reconstruction and description of modal frames of literary discourses; ${ }^{9}$ strengthening the conviction that deconstruction makes

${ }^{8}$ Deconstruction has an extensive body of texts and explanations in Poland. Here are some of the key texts: Tadeusz Rachwał, Tadeusz Sławek, Maszyna do pisania. O dekonstruktywistycznej teorii, Warszawa 1992; Poetyka bez granic, ed. by Włodzimierza Boleckiego i Wojciecha Tomasika, Warszawa 1995; Ryszard Nycz, Tekstowy świat. Poststrukturalizm a wiedza o teraturze, Warszawa 1995. The anthology of texts on deconstruction is of particular importance: Dekonstrukcja w badaniach literackich, ed. by Ryszarda Nycza, Gdańsk 2000. Derrida's views are discussed in, e.g., Michał Paweł Markowski Efekt inskrypcji. Jacaues Derrida i literatura, Bydgoszcz 1997. Anna Burzyńska gives a synthetic picture of deconstruction in Krajobraz po dekonstrukcji. (part I), op. cit., W stronę polityki. (Krajobraz po dekonstrukcji, part. II), „Ruch Literacki” 1995, i. 2, 194-221. Marta Mizuro writes about deconstructionist practise and theory in Dekonstrukcja jako strategia interpretacji, „Acta Universitatis Wratislaviensis. Prace Literackie”, v. 36 (1998), 197-206. Piotr Łaciak explains deconstructionist understanding of a 'play', Dekonstruktywizm - teoria gry źródłowej czy pojęciowej?, „Principia”, v. XXI-XXII (1998), 1

${ }^{9}$ See. Katarzyna Kasztenna, op. cit. 
the literary research from the historical perspective impossible, ${ }^{10}$ or that it, anyway, has little to offer in this respect. ${ }^{11}$

It seems that we have a distinct controversy about the ways in which literature could be studied. Post-modernist thought is full of different mechanisms of violence directed towards the text. An impression can be drawn that because of the a priori rejection of the possibility of rendering the results of reading in an objective way, deconstructionists focus on one-important, but probably not the only one-creative aspect of reading. The approaches to literary studies influenced by post-Kantian philosophical tradition to a lesser extent, and more concerned with the reader's experience, also focus on another-'passive' aspect of reading. The representatives of 'thematic criticism' were the most radical about it: Georges Poulet stressed that:

To read [...] is to make a sacrifice of one's habits, desires, convictions. ${ }^{12}$

Studying literature is here not so much oppressive forcing on to the text by a scholar of the cognitive categories interiorized by her (which are sometimes sets of fashionable research tools), but maximum openness to its separateness, a specific reliance on its voice, surrender to its claims. We can all observe an 'ethical shift' in literary studies, which induces more sensitivity towards text's 'difference', towards a necessary openness of a reader towards this text. ${ }^{13}$

\footnotetext{
10 This is the view held, among others, by Janusz Sławiński Miejsce interpretacji, „Teksty Drugie” 1995, v. 5, 27-29.

${ }^{11}$ See Stefan Stawiński: Wartość - sacrum - Norwid. Studia i szkice aksjologicznoliterackie, Lublin 1994, 40.

12 Georges Poulet, La conscience critique, Paris 1971, 104 [trans. G.M.].

13 See, e.g. Michał Paweł Markowski, Zwrot etyczny w badaniach literackich, "Pamiętnik Literacki" 2000, i. 1, 242. The 'ethical turn' has been extensively discussed in a special volume of "Teksty Drugie" (2002, no. 1-2).
} 


\section{Towards the Ethics of Reading}

Does this controversy have, after all, any importance for the problem of the monograph we are dealing with here? It seems that it has. It allows us to draw a general project of reading literature in the historical perspective. ${ }^{14}$ It is not new, but it is recalled so rarely that it seems as if it has been repressed from the contemporary awareness of literary scholars. In the extensive text by Stefan Sawicki Poczatki syntezy historycznoliterackiej w Polsce (Beginnings of Historical Perspective in Polish Literary Studies) we come across a fragment dealing with the contemporary ways of synthesizing diverse literary material, entangled in the diachronic perspective:

The description of the changes would be devoid of any frames and schemata taken a priori. Constructive receptivity would be the only methodological directive. ${ }^{15}$

Sawicki's suggestions seem to anticipate some of the proposals embedded in the contemporary ethics of reading. They impel the distance towards all pre-judgements of nature embedded in the theory of literature, or in ideology, and therefore they induce the responsibility for the research method and the language used. ${ }^{16}$ Sawicki's suggestions are far removed from setting norms of reading; he is content with sketching horizons for the ethical approach to literary texts. So, should we side with Katarzyna Kasztenna, who criticizes both the paradoxical nature of some of the Sawicki's claims and his maximalist expectations? Kasztenna wrote:

The expression 'constructive receptivity' is an oxymoron. It reveals the conviction about existence of some not fulfilled directives

\footnotetext{
14 Translator's footnote: In Polish literary studies the term "analiza historycznoliteracka" is used to refer to the way of reading literature which in Anglophone literary studies is now, retrospectively, referred to as the Liberal Humanist approach. 15 Stefan Sawicki, Początki syntezy historycznoliterackiej w Polsce. O sposobach syntetycznego ujmowania literatury w 1 połowie w. XIX, Warszawa 1969, 213-214. 16 See, e.g., Mieczysław Dąbrowski, Projekt krytyki etycznej. Studia i szkice literackie, Kraków 2005.
} 
which guarantee a creation of an ideal synthesis, which I consider as illusory. ${ }^{17}$

The phrase 'ideal synthesis' is puzzling. If it was to be the result of absolute cognition, Kasztenna's scepticism should be followed. It is difficult to imagine that even the most gifted researcher would attain this level of insight into reality which traditional epistemology ascribes only to God. If, however (as seems to be the case) Sawicki means a type of cognition which is available to people, if he is after pointing to the most general borders of scholarly reception of literary works and in so doing wants to protect them from reading which is narrow, oppressive, not ethical-athen, we must admit that Kasztenna's objections are not well founded and they betray a particular type of dogmatism in the ways of studying of literary texts. Unlike Kasztenna, I consider the phrase 'constructive receptivity' to be very appropriate, and I am convinced that it captures well the very essence of an honest study of a literary text. After all, ethical reading means both the active participation of a reader-who cannot lose his/her subjectivity when confronted with the text-as well as the openness to the 'other'; and respect for the autonomy (if we want to avoid the term 'subjectivity') of the text. Is it not so that this oxymoron-while pointing at some deficiency, heterogeneity of perceptive processes-shows one of the most characteristic features of man's cognition (study) of the world; not only of the textual world?

How can this principle of simultaneously being active and passive actio and contemplatio be put into practice in the case of a study which aims at the synthetic assessments of works by one writer? Can we-while remembering our own limitations (connected, among others, with such things as one sided research methods, linguistic inefficiencies, limited imagination and sensitivity) and with the limitations of the synthesizing process itself-verify the genre of the monograph in a scholarly manner? It seems that the idea of the subjectivity of reading, recurrent in literary studies, and the idea of the necessity of taking into consideration during reading the area

17 Katarzyna Kasztenna, op. cit., 19. 
W. KUDYBA, "A MONOGRAPH IS NECESSARY..."

of values (which is argued for by the contemporary ethics of reading), inducing a shift towards interpretation, ${ }^{18}$ return to an author ${ }^{19}$ and to axiology. ${ }^{20} \mathrm{I}$ am using the word 'return' consciously-remembering not only the quaint 'death of the author', but also the contemporary controversies about interpretation, and finally that only some of many of contemporary research methods have been concerned with values. It is difficult to suppose that it would still be possible to return to the old methods of reading literature. I think, however, that it is possible to read a text in order to reveal the values hidden in it, that it is possible to implement an interpretation which would use the most contemporary of analytic tools from literary studies

${ }^{18}$ The theme of the 'return of the author' was dealt by Małgorzata Czermińska, Wygnanie i powrót: Autor jako problem badań literackich, w Kryzys czy przełom: Studia $z$ historii i teorii literatury, ed. by M. Lubelska and M. Łebkowska, Kraków 1994, 165-173. Contemporary debate about these issues has been presented, among others, in Teksty Drugie, 1994/4. 1991/1-2 and in Ja, Autor: Sutuacja podmiotu w polskiej literaturze współczesnej, ed. by D. Śnieżka, Warszawa 1996, Osoba $w$ literaturze i komunikacji literackiej, ed. by E. Balcerzan, W. Bolecki, Warszawa 2000 and in Janina Abramowska, Podmiot, osoba autor, in Sporne i bezsporne problemy współczesnej wiedzy o literaturze, ed. by W. Bolecki, R. Nycz, Warszawa 2002, 99-112.

19 One of the scholars writing about 'the return of the author; is Małgorzata Czermińska: Wygnanie i powrót. Autor jako problem badań literackich, in Kryzys czy przełom. Studia $z$ teorii $i$ historii literatury, ed. by Magdalena Lubelska and Anna Łebkowska, Kraków 1994, 165-173. Contemporary controversies about this notion are presented in "Teksty Drugie": 1994, no.4 and 1999, no. 1-2 and in Autor, podmiot literacki, ed. by Anna Matuszewska and Janusz Sławiński, Wrocław 1983; Ja, autor. Sytuacja podmiotu w polskiej literaturze wspótczesnej, ed. by Dariusz Śnieżka, Warszawa 1996; Osoba w literaturze i komunikacji literackiej, ed. by Edward Balcerzan and Włodzimierz Bolecki, Warszawa 200o. The idea of the 'absence' of the author in literary studies is discussed by Janina Abramowska in Podmiot - osoba, in Sporne i bezsporne problemy współczesnej wiedzy o literaturze, ed. by W. Bolecki and Ryszard Nycz, Warszawa 2002, 99-112.

${ }^{20}$ Axiology in literary studies has been extensively analysed by scholars of Polish literature from Lublin in, e.g., $O$ wartościowaniu $w$ badaniach, ed. by Stefan Sawicki and Władysław Panas, Lublin 1986; Problematyka aksjologiczna w nauce o literaturze, ed. by S. Sawicki and Andrzej Tyszczyk, Lublin 1992; Interpretacje aksjologiczne, ed. by W. Panas and A. Tyszczyk, Lublin 1997. 
(for example connected with the intertextuality of literary texts) and to take into account the fact that it is the author who is both a constructor and a 'host' in the textual world. The strategy of reading which I am particularly partial to could be called 'liberal', 'inclusive' (in contrast with dogmatic 'exclusive' strategies), a strategy which is symbolized by the sentence: 'not only... but also'. I would wish, therefore, not only to attempt to build some conceptual wholeness, revealing the key features of works of a given author, but also to draw attention to the semantic equivocalness of literary works and their "mystery". Not only about reading aimed at showing the opacity of a text, but of that which patiently attempts to shed some light on different meanings based on solid, almost 'philological' analysis of individual lines. I consider as interesting both the intertextual dimension of a given text and its closest, internal contexts. ${ }^{21} \mathrm{I}$ am aware of the fact that the relationships of an author with the work are very complex. I am not much concerned, anyway, about the relationships of the work with the biography of its author. Similarly to some other contemporary researchers, I am willing to accept the claim that the relationships between a text and an 'autobiographical author' can be explained through such notions as 'signature', 'trace' andin the case of a sequence of works- of the 'author's hypothesis. ${ }^{22}$

\footnotetext{
${ }^{21}$ I am not concerned here with the so called, "total intertextuality" and of analysis of all possible textual associations of a given reader, both with texts earlier and later than the analysed one. Similarly to many contemporary researchers I regard this type of intertextuality as not operative and difficult to apply in literary studies. In this paper I use the notion of intertextuality in a narrower sense, limiting it to conscious, intentional and marked (by an author) references which are inspired by a particular text or a group of texts. The wider sense of intertextuality is discussed, among others, by Ryszard Nycz, Tekstowy świat. Poststrukturalizm a wiedza literaturze, Warszawa 1995, 59-82; Manfred Pfister, Koncepcje intertekstualności, „Pamiętnik Literacki” 1991, i. 4, 183-208; Anna Wójcik, Co to jest intertekstualność, „Roczniki Humanistyczne” 1998, i. 1, 114-128, Michał Głowiński, O intertekstualności, in Idem, Intertekstcalność, groteska, parabola. Szkice ogólne i interpretacje, Kraków 2000, 5-33.

${ }_{22}$ See Małgorzata Czermińska, Hipoteza autorstwa. (O podmiocie dziel wszystkich jednego autora), in Ja, autor. Sytuacja podmiotu w polskiej literaturze wspótczesnej, op. cit., 79-88.
} 
W. KUDYBA, "A MONOGRAPH IS NECESSARY..."

I am inclined, however, to use the category of 'author', mostly from the perspective of a 'person as a writer'-a personal creator of a text, to whom we can logically ascribe using this or that type of poetics, having a specific type of poetic imagination, constructing a specific vision of the world and specific key characters. I am most interested in attempts on the part of an author ${ }^{23}$ to organize a text in such a way that it evokes some values. ${ }^{24}$ That is the synthetic and general way of describing a field of decisions within which I consider the writing of monographs not only as not necessary, but also as possible.

\section{Theory of Practice, Practise of Theory}

Let us return, however, to the theory of the monograph. Although the old tradition preferred the diachronic approach, developed in accordance with the chronology of an author's biography ${ }^{25}$, today it is synchronic approaches which prevail. ${ }^{26}$ Probably not a single literary scholar, aware of his/her profession, believes in "total" explanation of the interpreted works. Usually, a few aspects, or even just one aspect, are selected which are important and focus on key specific feature ${ }^{27}$. This choice, I believe, should be justified not by the right to "play with a text" in a free way but by, first of all, the existence of some "interpretative community", and therefore by the existence

\footnotetext{
${ }^{23}$ This type of author is obviously derived from text of Vinogradov "author's image” or Janusz Sławiński's "podmiot czynności twórczych" ("subject of creative activities") However, I also rely on more recent research. See Stefan Sawicki, Między autorem a podmiotem mówiącym, in: Poetyka. Interpretacja. Sacrum, op. cit., 84-110; Also Stefan Sawicki, O sytuacji w metodologii badań literackich, op. cit., 33-47.

${ }^{24}$ The axiological aspect of reading of literary texts is extensively discussed by Stefan Sawicki in his paper: Problematyka aksjologiczna $w$ badaniach literackich, w: Problematyka aksjologiczna w nauce o literaturze, ed. by S. Sawicki and Andrzej Tyszczyk, Lublin 1992, .95-109.

${ }_{25}$ As Sawicki explains the monograpahs by Juliusz Kleiner about Mickiewicz, Słowacki and Krasiński. See O syntetycznym ujmowaniu literatury, op. cit.

${ }^{26}$ This is the way in which monographs published by Wydawnictwo Literackie are constructed.

27 Stefan Sawicki describes such a type of contemporary monograph in O sytuacji $w$ metodologii badań literackich, op. cit., 45.
} 
of some ethical rules of reading ${ }^{28}$. I think that it is the "norms of reading" existing in our culture which help to achieve the situation in which the judgement about the key features of any literary texts would go through the process of "objective assessment" - however, imperfect it may be - which will safeguard against arbitrariness and violence performed on the text. Such judgements make our research procedures verifiable, although I am aware that their character is not absolute and timeless.

As Stefan Sawicki argued, the technique of synthesizing used in monographs requires a separate comment. It is the idea of representation which is crucial here. ${ }^{29}$ This idea is at the basis of the compositional decisions discussed above. A monograph can provide an assessment of all the works of one writer thanks to detailed and extended analysis of one, important aspect of these works. The use of the idea of representation is also connected with the obligation to choose texts regarded as most representative, that is revealing-in manners artistically most interesting - their features and focusing on these particular texts. ${ }^{30}$ It does not mean, however, that a monograph must be totally devoid of elements of a general nature which allow us to gauge the 'quantitative' density of some of the features of the writer's poetics, and also of the frequency of occurrence of some motifs, ideas, visions, and their importance. I am aware that these observations are a common treasure of literary scholars-often taken for granted, but rarely focused upon. Is it because they appear to be old-fashioned? Unfashionable?

\footnotetext{
28 'Interpretative community' is not so much a group of people as "a bundle of strategies of interpretative norms we have and which regulate the ways we think and perceive. Cf, Henryk Markiewicz, Staroświeckie glosy, „Teksty Drugie” 1997, no. 6,47 .

29 Stefan Sawicki, O syntetycznym ujmowaniu., op. cit.

30 The 'representative approach" is discussed by Stefan Sawicki in: O syntetycznym ujmowaniu literatury, op. cit., 168.
} 
Perhaps it is worth starting research about research fashions? If anthropology of literary studies existed, if we put under scholarly scrutiny the particular social practise of theory, we would perhaps discover the reasons behind the ambiguous status of the monograph. Maybe its author, if he/she seriously approaches the voice of the text which has been read, if he/she could listen to its demands-about the research methods, language of description, etc.-would be forced to adopt the role of the 'other; "A historian of literature (focused on synthesis) is not professionally fashionable"-wrote Jerzy Ziomek some time ago. And he added: "It happens very rarely that synthesis is a methodological dernier cri" ${ }^{31}$ Maybe the oppressive nature of theory is not based solely on the fact that it narrows the field of observations and inclines us to look at a given text exclusively through the lens of tools characteristic for a given method, even though an analysed text not only did not encourage the application of these particular tools, but even did not allow them (the Marxist way of reading would here be just one example of such a situation). It is perhaps equally important that theories seem to suspend, or even nullify, the imperative of fidelity towards a text and its social context, which is constitutive for the history of literature. This imperative is replaced by another one-to use new and not always good-a research tools. A new vista for research is opening. Let us hope that it finds its own commentators.

${ }^{31}$ Jerzy Ziomek, Metodologiczne problemy syntezy..., in Problemy metodologiczne współczesnego literaturoznawstwa, op. cit., 33 . 